\title{
INTERNATIONAL FINANCIAL INSTITUTIONS SYSTEM AS A FACTOR OF TRANSFORMATION OF NATIONAL CURRENCY SYSTEM
}

\author{
Andrii OLIINYK ${ }^{1}$ \\ Kyiv National University of Trade and Economics, Ukraine
}

\begin{abstract}
The purpose of the paper is to analyze theoretical and practical aspects of the features of the IFI influence on transformation of national currency systems of such organizations' member states. Defining features of interaction policy among national economies and IFI in the monetary sphere, considering countries' socio-economic parameters of development, will allow monetary authorities to achieve the optimum level of development of its economy. Methodology. Theoretical base of the study are the provisions of general scientific theory of knowledge studied phenomena and processes, in particular: methods of induction and deduction (in determining classification criteria of IFIs impact on national currency system), analysis and synthesis (in determining the features and priorities of national currency system), comparisons, associations and analogies (the justification of characteristics of advantages and disadvantages of IFI). The information base for scientific research is scientific papers and publications of domestic and foreign scientists-economists, materials of scientific-practical conferences, legislative and normative documents, the IMF, World Bank and Asian Infrastructure Investment Bank materials. Results. Theoretical approaches to the definition of the national currency system and international financial organizations, including its classification, are proposed. It is proved that the IMF makes active impact on national currency policy formation through regulation and supervision, while the World Bank and AllB are related in a passive way. The IFI regulation trends are to implement floating exchange regime, liberal currency transactions, cancel currency restrictions in member countries. Although it refers to all countries, some of them with large population, trading, underdeveloped institutions of democracy could avoid some IFI pressure. Practical implications. The study accents attention on the specifics of the IFI activity in terms of changing the currency policy of member countries. Comparison of priorities among national currency policy and IFI recommendations could be applicable for national authorities in performing national currency policy. Value/originality. Despite the existing studies in the field of international monetary policy, there is a gap in theoretical definition of interaction between IFI and national monetary authorities in the field of national currency policy forming at present. This article brings new approaches to the IFI classification and approaches to the definition of IFI characteristics in terms of impact on currency policy of member country.
\end{abstract}

Key words: International financial institution, national currency system, exchange rate regime, International Monetary Fund, World Bank, Asian Infrastructure Investment Bank.

JEL Classification: E52, F30, F31, G20

\section{Introduction}

In today's context of globalization, an important role is brought to international financial institutions (IFI) in regulation of financial and foreign exchange environment of countries. Globalization and regionalization are opposed vectors of economic development and determine the direction of national economies in choosing their own concepts of currency policy. It is clear that these processes do not take place without the intervention of international regulation of financial institutions. Scientific interest is related to conditions and vectors of impact

Corresponding author:

${ }^{1}$ Department of International Economic Relations, Kyiv National University of Trade and Economics.

E-mail: oliynik12@gmail.com of IFI (including the IMF, World Bank and Asian Bank for Infrastructure Investments) on national currency system, theoretical definitions of national currency system structure, priorities, IFI policy.

\section{National currency system} and national currency policy priorities

Considering the IFI cooperation with countries on forming their own national currency system, it should be decided on the nature of the national currency system, its structure and priorities for the currency policy. 
Money is one of the main component of the monetary system, which is considered to be analyzed both from a narrow and broad point of view. From a narrow point of view, money is identified with coins and notes that in the particular country are legal tender, and function as world money abroad. From a broad point of view, money is not just coins and banknotes, but also claims that take the form of promissory notes, checks, bank deposits. Some Ukrainian scientists, combining these two definitions, describe the concept of „currency” as the funds that are directly or indirectly related to external relations (Slavuk, 2006).

As a money unit, the currency must also perform the same function as the money, but the main difference between the two is their scope of application. Currency operates outside the state and creates international monetary relations, and money operates within the state. As L. Krasavina suggests, „currency” as a category provides relationship and interaction among participants in the global economy (Krasavina, 2010). Since currency outside the country enters into a relationship with the currencies of the world through convertibility, it provides the basis for the globalization of financial markets, efficient international trade and development of international monetary relations.

"System" is a second category and is defined as a set of objects whose interaction causes new integrative qualities, which is not inherent for separate elements (Orekhova, 2007). The main feature of the system is the interconnection and interdependence of its elements together that are stable and the operation of the system can make the transitions from one state to another. This feature reveals the essence of the currency system at the most accurate way.

From economic point of view, currency system is a combination of monetary and economic relations historically based on the internationalization of economic relations.

From organizational and legal points of view, currency system is a state-legal form of currency relations of the country, which was developed historically on the basis of economic relations internationalization and it is enshrined in national legislation according to the norms of international law (Mozgovyi, 2005).

It should be noted that national currency system is a part of the monetary system of the country and can perform an independent function in the country's participation in the implementation of international monetary relations (Borynets, 2004). For example, scientists examine national currency system from the perspective of economic relations for international settlements, creation and use of a basket of currencies that are a part of the national monetary system.

That is because all these systems are linked closely and together reflect the situation in the financial sector of a certain environment (national or international). Thus, from our point of view, currency system is one of the main components of the financial system, as shown in Fig. 1.

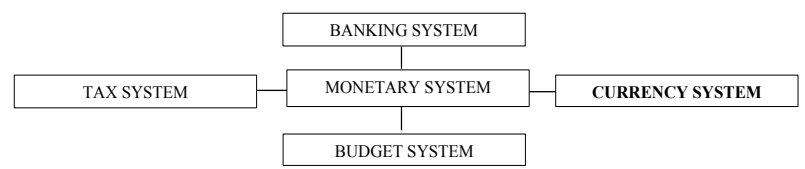

Fig. 1. Financial system structure

Due to the systems relationship, there is a considerable interdependence not only between systems and between different elements of different systems. For example, one element of the currency system - the exchange rate affects not only the elements of the currency system (gold reserves, foreign exchange market, monetary policy, etc.), but the elements of monetary, credit and banking systems (issue of currency, interest rates loans and deposits, established norms of bank reserve, stability of banking and financial institutions and others).

In the context of the subject it is proposed to consider national currency system as a set of economic and monetary relations, which provide currency functioning for foreign economic relations of the country, the creation and use of monetary resources that legally are enshrined by the state legislative acts, including regional standards, international rights and ensuring the competitiveness of the national economy under the influence of factors of globalization and institutionalization of the international financial and monetary relations.

The main structural elements of the national currency system are (Dzyublyuk, 2007): currency, convertibility of currency, exchange restrictions, exchange parity and exchange rate regime, international currency liquidity and reserves, foreign exchange market and gold market, international payments regulation and international currency relations, national authorities that are entrusted to develop and implement currency policy.

Each of the elements of the national currency system is always at some stage of development or transformation. For example, a change of national means of payment into foreign, restrictions on foreign exchange transactions or currency market liberalization, changes in the exchange rate regime. In general, such a transformation depends on the priority of currency policy of the country to achieve certain macroeconomic indicators of the economy. Today, most governments of the world are developing such objectives of currency policy that would:

- maintain a balance of payment operations or receive a payments surplus to stimulate the economy;

- ensure the stability of the exchange rate;

- form the monetary stability of the economy.

In the final case, the main purpose is the creation of conditions for effective functioning of the economy based on the formation of market players' trust towards monetary authorities, which ultimately improve the investment climate in the country. 


\section{Institutionalization of world monetary system regulation: causes and genesis}

Proposals on the creation of the IFI, which would be involved in the regulation of exchange relations, appeared in the late 20's of the 20th century. Before that time issues in economic relations were resolved by each state, any universal multilateral regulation was absent (Neshataeva, 1993). The need for universal regulation of economic relations was justified by the following reasons: firstly, the negative effects of imbalances of one economy on another caused by the global economic crisis in 1929-1930; secondly, the constant growth of foreign trade turnover among individuals and legal entities in different states; thirdly, the close interdependence between world market prosperity and national economies.

The obvious connection between slowdown of international economic cooperation and a decrease in the European market after the World War II turned Western economists and lawyers to argue about the necessity of uniform, universal international legal regulation of international economic relations.

The first international financial institution - the Bank for International Settlements was established in 1930. Its work filled monetary and financial segment of VersaillesWashington system of international relations, in which the interaction of states was governed by the rules of Genoa monetary system. In 1933 according to the initiative of the League of Nations an international economic conference was convened to search for measures that would as soon as possible remove barriers from international trade and facilitate the necessary measures to stabilize the currency and restore lending (Tsygankova, 2001). However, the significant differences between member states did not allowed reaching the stated goals.

The crisis of the international monetary and credit relations during the Second World War found its expression in the introduction of currency restrictions. Money turnover of most countries had inflationary feature because of chronic government deficits. Global economic ties were broken. It was necessary to normalize international economic relations of states, especially enhance international trade and adequate development of the international monetary and financial relations. However, there were currency restrictions on its way. Thus, at the end of the World War II the leading countries of the world began to find ways to stabilize the international monetary and financial relations, based on the need for multilateral monetary agreements between states (Khoroshkovsky, 1999).

At the Bretton Woods conference there was produced a compromise and defined organizational structure of the international economy after the World War II. Delegates approved the decision to establish the institutional foundations of the world financial system, namely the International Monetary Fund to recreate and stabilize the international and national monetary and financial systems and the World Bank (International Bank for Reconstruction and Development, hereinafter - IBRD) to promote private capital to expand investment lending.

The creation of these two international organizations (the so-called „Bretton Woods sisters”) launched a new phase of international economic relations, which since have acquired the character of a supranational regulation and management. In modern terms, they establish "game rules" in the monetary and financial sector for most countries. Internationally, organizations serve as the primary regulator for the implementation of the single currency policy of the member states.

\section{International financial institutions systems: theoretical approaches and classification}

Considering the approaches to the definition of the IFI, one could argue that they are an integral part of the institutional structure of the world economy. On the one hand, these organizations regulate the international monetary and financial relations based on their power and resources. On the other hand, it is a forum for intergovernmental discussion of monetary, credit and financial policies, and it provides storage and systematization of information on current monetary and financial problems and the economy as a whole.

In economic science IFI is an international economic organization based on international agreements to regulate currency and financial relations between the member countries, promoting economic development and providing credit assistance (Krasavina, 2010), as well as for research in monetary and financial areas of the world economy, providing recommendations and proposals. Hence, the activities of these organizations are aimed at achieving the following objectives:

- Joint efforts of the international community to stabilize international finance and the global economy;

- Implementation of interstate exchange, credit and financial regulation;

- Joint development and coordination of strategy and tactics of the world monetary and credit and financial policy.

IFI are created by combining the financial resources of the member states to solve problems of the global economy. These tasks can include: 1) transactions on the foreign exchange and stock markets to stabilize and regulate the global economy, support and promote an international trade; 2) provision of international credits, particularly in the implementation of public projects and budget deficit financing; 3) investment activities and financing in the „internal” projects which makes a positive impact on international business; 4) financing international aid programs and fundamental research.

Some states use IFI to conduct their own policy; others use them as donors, and others - as recipients, and work with them to raise funds for investment and solving deficits problem. 
Classification of the IFI is based on many criteria. In particular, I. Gerchikov classifies international economic organizations, which are in charge for regulation in the world economy, relying on the organizational principle and he distinguishes: a) organizations of the UN system; b) organizations that are not part of the UN; c) regional organizations (Gerchikov, 2001).

Classification, that is more detailed, is offered by A. Rogach (Rogach, 2003), who groups IFI by a number of criteria, including:

- Number of members: 1) general organization potentially designed to the participation of all states; 2) restricted organization, which involves only group of countries;

- Nature of competence: 1) organizations which have the overall competence; 2) organizations with special competence;

- Ratio of volume competencies: 1) intergovernmental organizations, which perform coordinating functions, where competence is shared and is redistributed among states and organizations; 2) organizations that perform certain supranational functions and have exclusive competence in a number of functions and limit member states; 3) supranational organizations established to create the rules for member states and mechanisms for compliance monitoring;

- Sphere of international regulation: 1) international economic organizations, which govern economic and industrial cooperation and areas of world economy; 2) international economic organizations that govern global trade; 3) international monetary and financial organizations; 4) international and regional organizations that regulate business activity; 5) international nongovernmental organizations and associations that promote economic relations.

According to the classification of M. Pebro, international organizations can be divided into four main categories (Pebro, 1994):

1) organizations, which are designed to deal with worldwide problems and were created after the World War II;

2) organization, established by initiative of the Western countries, which unite developed market economies;

3) organizations involved in the European development;

4) various institutions for regional or bilateral cooperation.

T. Tsygankova, T. Gordeeva et al. (Tsygankova, 2001),

distribute IFI on global and regional ones. So-called „Bretton Woods institutions” which include the International Monetary Fund (IMF) and World Bank Group (WB) referred to global institutions. Regional IFI, which sometimes referred to „regional development banks", include the European Bank for Reconstruction and Development (hereinafter - EBRD), the Inter-American Bank of Development (IDB), Asian Development Bank (hereinafter - ADB), the African Development Bank (hereinafter AfBR).

As part of the subject, the classification of IFI based on the following criteria is proposed:
1. According to the existence of impact on a national currency policy formation: 1) containing the required currency regulations, 2) provide an explanation recommendatory, 3) neutral to regulate the national currency system or the transformation of its elements.

2. According to the feature of influencing on national currency system:

- Active influence, which is characterized with the formation of normative principles of national currency policy, overseeing the functioning of the currency system, the provision of borrowed resources under certain measures of currency policy;

- Passive impact associated with input/output of foreign currency to the national economy and, thus, the spread of the foreign currency in a country occurs under the pressure on the balance of payments, especially, if the funds are used inefficiently. While specific requirements to change the mode of the elements of the national currency system are absent, however, it creates the foundation for the liberalization of payments. In addition, some IFI coordinate their monetary policies with others IFI, which exercise an active influence on the formation of member country currency policy.

\section{IFI activity features in national currency policy formation}

The current institutional structure is characterized with an extensive system of international organizations and institutions, which includes both global and regional monetary and financial institutions. Significant role in the concentration of financial resources and regulation of the modern world economy play such IFI as the Bretton Woods institutions, the Bank for International Settlements (BIS) and the bank of regional specialization (the African Development Bank, Asian Development Bank, Inter-American Development Bank, Asian Infrastructure Investment Bank etc.).

The main IFI, which will be considered in this study, are the IMF, the World Bank Group (IBRD, IFC, IDA, the regional affiliates, such as $\mathrm{EBRD}, \mathrm{ADB}, \mathrm{AfBR}$ ) and $\mathrm{ABII}$.

The IMF (Fund) is an intergovernmental organization created to regulate monetary relations between member states and provide them with financial assistance in exchange difficulties, caused by balance of payments deficit with the help of loans in foreign currency.

Today, this IFI has a key role in the global financial system and performs essentially the function of lender of last resort.

Providing loans, the IMF must be sure that this country has a policy designed to eliminate the problems of external payments. In exchange for financial support of the Fund, the country undertakes to accomplish the correct measures to ensure that the country is able to repay its debt to the Fund and provide, thus, fulfilling of its credit. Therefore, unlike other sources of external financing, the IMF and the World Bank branches have a special place in the external relations of credit borrowers. 
In its credit policy the IMF is governed by the following basic principles:

- Borrowing country should be ready to apply measures to overcome problems with its balance of payments;

- Policy of the country should be compatible with the objectives of the IMF and help prevent the introduction of trade and currency restrictions;

- Policy of the countries should be aimed at overcoming the problem of payments for an extended period;

- Policy of the country should lead to an increase in its foreign exchange reserves so that it could repay its own national currency to repay the IMF loans.

Thus, the national currency policy of the borrowing country should be compatible with the principles of the temporary use of IMF resources, and this principle, according to the Fund, is in favour for all countries.

The doctrine of the conventions, which constitute the above principles, acts as an instrument of interstate regulation, which allows the Fund to use credits for active influence on the whole complex of social and economic relations of countries that use its resources.

Loans provided by the Fund to many countries are particularly important because they act as a catalyst in attracting other financial resources can significantly exceed the size of financial assistance of the IMF.

The main role of the IMF is to strengthen monetary cooperation and maintain financial stability. To achieve these goals, the IMF has the right to oversee the exchange rate policies of members. In practice, the Fund performs particularly multilateral surveillance, or advising on economic policy of each member state, analyzes economic policies, collects data and announce them. The presence and supervision of the IMF over exchange rate policies of member countries is related to the imposition of liability, which are determined in accordance with the recommendations of the Fund experts (Demkivskyy, 2014). It appears a significant political pressure on monetary authorities, as data of member country on foreign exchange reserves and policy interventions are published regularly.

Some politicians do not have enough experience in managing monetary and interest rate, and may not fully take into account the risks of changes in monetary policy. Thus, in this context, the IMF can act as a union of states and a common forum to address such problems.

As a part of the study it is found the degree of influence of the IMF and indicators of socio-economic development in following the announced exchange rate policy by member countries. The results indicate the presence of the inverse relationship between the number of announcements and publications about IMF member country and possibility of deviation from the floating exchange rate regime $(\mathrm{R}=-0,09)$. The „fear of pegging” is positively correlated with the supervision of the Fund (0.061). This is explained by the doctrine of the IMF for liberalization of currency relations and a greater favour to floating exchange rates. According to statistics of G. Minne (Minne, 2013), the probability of deviation from the floating exchange rate decreases by 2.18 percentage points averagely with the release of a publication about IMF members. Moreover, the deviation threshold for probability decrease is higher for countries with small economies that are not under Fund's scrutinize surveillance. Thus, the influence of the IMF on exchange rate policies of member countries is quite significant, although it can be negated with largest economy, the share of country's trade in world's GDP.

The population has a positive effect on the propensity to use in fact the fixed exchange rate regime instead of floating one. This explains, for example, the ability of China, India and Russia to conduct its own currency policy. The level of democracy has a negative correlation with the fear of floating for exchange rate regime, as democratic countries have an incentive to reduce the uncertainty to attract foreign investment better. Increased capital flows adjustability reduces the likelihood of deviation from the chosen exchange rate regime. An economic growth rate stimulates to preserve exchange rate parities and consequently causes a negative impact on the probability on deviation from the fixed exchange rate and positive on the probability on rejection of the floating exchange rate. That is, it is necessary to stabilize the country's exchange rate volatility if the undervalued exchange rate is a source of national economy growth.

One of the main factors that determine susceptibility to deviations from the officially announced exchange rate regime is the level of institutional quality authorities. Thus, countries with high levels of corruption and low protection of property rights are less able to comply with commitments to fixed exchange rate. It shows their inability to support macroeconomic stability. It also explains the existence of dual exchange market in the country, which increased demand for foreign currency „presses” on the course and creates a temporary „black market”. While countries with developed institutions experience „fear of floating”, as they seek to ensure the stability of development and reverse the volatility of the exchange rate.

International Bank for Reconstruction and Development was established in 1944 to ensure international flow of long-term investments to assist in restoring the economy of countries devastated by war.

After 1952 when the countries of Western Europe acquired a certain economic independence the Bank's focus gradually shifted towards measures specifically designed for developing countries. These changes were caused by the release of significant number of young independent states; by a change of the former colonies and dependent countries in the world economy; by the struggle of various forces in the world around the issue of selecting ways of development, especially for countries, which gained independence.

All this was reflected in the statutory purposes of the international financial organizations, contained in Bretton Woods. According to the Statute, the Bank has the following objectives: encouraging investment in member countries 
for productive purposes; encouraging private foreign investment and supplement them, if necessary, by its own loans; providing guarantees for private foreign investment; promoting the balanced development of international trade and balance of payments support; encouraging economic development in the poorest countries; assistance to member countries in the reconstruction and development of their territories; assistance to developing countries through longterm financing of projects and development programs; giving special financial assistance through the International Development Association to the poorest countries; support of the private enterprises in developing countries through its location - International Finance Corporation.

But the Bank is not only a source of external funding for developing countries, but it is also an important center of development, support and implementation of the development strategy of the „third world." The World Bank has a unique opportunity to promote greater awareness of the member states on the most advanced practices in the field of economics and effectively distribute the necessary knowledge among whom it assists.

At the beginning of the 20th century, there was an IBRD membership of 180 countries. Membership in the IBRD is interconnected with membership in the IMF. Hard binding of IBRD Charter (Sec. 1, Art. 2, Sec. 3, Art. 6 of the Statute) with membership in the IMF is related to the fact that member countries of the World Bank are required to conduct monetary policy in accordance with the provisions of the IMF. Therefore exclusion from one financial institution entails loss communications with another.

One of the main forms of monetary system growth of the People's Republic of China (PRC) in the XXI century was the creation of a new regional international formation - Asian Infrastructure Investment bank (ABII). According to many economists, this project is aimed to the implementation of the „Silk Road” for the development of transit countries infrastructure with the aim of closer China's economic cooperation as with the EU, so with neighbouring countries. It also entails the prevalence of the use of the yuan in international calculations, particularly among the member countries of the project. This concept of development is important from the perspective of avoiding of Chinese economy "overheating”, and promoting the free flow of Chinese capital to neighbouring countries via comprehensive use of the Chinese currency.

According to scientists (Rogovyk, 2015), ABII creation is a continuation of the Chinese policy on strengthening the yuan as a reserve currency. Back in 2013, the Chinese authorities announced the organization of the "Silk Road”. On October 24, 201421 Asian countries (led by China), 7 Arab countries, 17 EU member states joined the Memorandum of Understanding on the establishment of a multilateral intergovernmental financial institution (AIIB). Thus, the share of Asian members accounts for $75 \%$ of voting shares.

As of 07.25.2016 the Bank has received applications for funding infrastructure projects totalling \$ 742.77 million dollars of the US, of which endorsed 301.74 million dollars of the USA.

In our opinion, the ABII project is not so affected significantly the exchange rate policies of member countries, such as the IMF. According to the analysis, AIIB works more as the World Bank. According to recent statements by top management of the AIIB, projects funding will be entirely in US dollars. The ABII concept can reduce the share of the IMF in the Asian region, which will allow China to take global leadership, promote China as a country that supports the internationalization of the RMB and increase its contribution to the global financial system. The trade development will require stability in the monetary policy; therefore China will reach mutual countries understandings regarding transition to its own national currency. In addition, a broader use of national currencies of member countries in international exchange with China is facilitated with large number of agreements among the central bank of China and the central banks of member countries. Yuan is becoming more common in use in Vietnam, Kazakhstan, Mongolia, Uzbekistan and Thailand.

In addition, factors that will facilitate the spread of the yuan will be:

- Improving the integration of neighbouring economies to trade and industrial chain of China, increasing trade turnover with China's neighbouring countries and the EU;

Table 1

Transformation of national currency system elements under the impact of IFI

\begin{tabular}{|c|c|c|c|c|}
\hline № & National currency system elements & Active impact IFI & Passive impact IFI & Character of impact \\
\hline 1. & Currency & & IMF, WB, АБII & Dollarization of the national currency system \\
\hline 2. & Convertibility of currency & IMF & & Promoting free currency conversion \\
\hline 3. & Exchange restrictions & IMF & IMF, WB & Absence or presence of only a partial term \\
\hline 4. & $\begin{array}{l}\text { Exchange parity and exchange rate } \\
\text { regime }\end{array}$ & IMF & IMF, WB & $\begin{array}{l}\text { Priority to floating or regulated floating } \\
\text { exchange rate regime }\end{array}$ \\
\hline 5. & $\begin{array}{l}\text { International currency liquidity } \\
\text { and reserves }\end{array}$ & IMF & IMF, WB & $\begin{array}{l}\text { Promoting an active formation of foreign } \\
\text { exchange reserves }\end{array}$ \\
\hline 6. & $\begin{array}{l}\text { Foreign exchange market and gold } \\
\text { market }\end{array}$ & IMF & IMF, WB & $\begin{array}{l}\text { Limited monetary authorities intervene } \\
\text { in the currency market }\end{array}$ \\
\hline 7. & $\begin{array}{l}\text { International payments regulation } \\
\text { and international currency relations }\end{array}$ & IMF & IMF, WB & $\begin{array}{l}\text { Liberalization of foreign exchange settlement } \\
\text { and relations }\end{array}$ \\
\hline
\end{tabular}


- Increasing funding for Asian developing countries, through transfusions of Chinese investments;

- Absence of imposed requirements in currency policy for member countries in terms of obtaining investment from ABII.

ABII has a considerable potential to increase the use of Chinese currency in the member states through the efficiency and the importance of investment to neighbouring economies and the absence of the need to observe specific currency requirements.

Thus, having analyzed the main functions of the IFI activities it is offered the following distribution according to the area of impact on the elements of the national currency system (Table 1).

\section{Conclusions}

National currency system is a set of economic and monetary relations, which provide currency functioning for foreign economic relations of the country, the creation and use of monetary resources under the influence of factors of globalization and institutionalization of the international financial and monetary relations. The national currency system transformation is displayed in the form of its element adjustment.

The need for universal regulation of economic relations is justified by the reasons of the negative effects of imbalances of one economy on another, the constant growth of foreign trade turnover among individuals and legal entities in different states; the close interdependence between world market prosperity and national economies.

The classification of the IFI due to the possible impact on national currency policy and the nature of this impact demonstrate distinction between active and passive IFI, which depends on the features or the instruments, applied to member's country policy.

The research demonstrates the ambiguity of the objectives and tasks of the national currency system, facing the monetary authorities and the IFI. Key features in implementing of national currency policy of the country and priorities of the IFI are similar:

1. Ensuring a stable balance of payments;

2. Stability of the national currency of the member country;

3. Free convertibility of the national currency;

4. No restrictions on foreign currency transactions.

It remains problematic to conduct an independent currency policy for member country with a fixed exchange rate regime; large numbers of currency interventions, as a pressure of IFI, particularly the IMF to implement the agreements are significant. But for countries with a significant size of the economy, amount of people, even such pressure cannot force to implement IMF standards.

Most of the activities offered by the IMF and World Bank are advisory in nature. However, it should be emphasized that while IFI provide financial resources, these could be accompanied by imposed requires in national currency system.

For better interacting with IFI in the field of national currency system countries have to:

- use borrowed money effectively and obtained benefits in order to refuse from financing in the future and to form its own currency policy.

- transform its exchange rate regime to more flexible one, which would better attract investment in the long run, considering IFI data publication on each member country.

\section{References}

Aizenman, J. (2007). International reserves: precautionary versus mercantilist views, theory and evidence. Open Economies Review. (18): 191-214.

Borynets, S. (2004). International monetary and financial relations. - Kyiv. 409 p.

Demkivskyy, A. (2014). Money and Credit. - Kyiv, Dakor. 528 p.

Dzyublyuk, O. (2007). Monetary policy. - Kyiv, Znannia, 2007 - 423 p.

Gerchikov, I. (2000). International economic organizations: the regulation of global economic relations and business activities. - Moscow. Konsalbankyr. 622 p.

Khoroshkovsky, V. (1999). World Bank: Credit Resources of International Bank for Reconstruction and Development. - Kyiv. Intellect of the nation, 196 p.

Krasavina, L. (2010). Conceptual approaches for reforming the system of world currencies. Jornal of Money and Credit, (5): 48-57.

Levy-Yeyati, E. (2013). Fear of appreciation. Journal of Development Economics. 101(0): 233-247.

Minne, G. (2013). An International Watchtower: IMF Surveillance and the Fear of Declaring one's Exchange Rate Regime. - Fonds de la Recherche Scientifique, 41 p.

Mozgovyi, A. (2005). International finance. - Kyiv. Kyiv National University of Economics. 504 p.

Neshataeva, T. (1993). The World Bank and The International Monetary Fund. Moscow Journal of International Law: 82-98.

Official website of the Asian Infrastructure Investments Bank. Retrieved from: http://www.worldbank.org/

Official website of the International Monetary Fund. Retrieved from: http://www.imf.org/external/index.htm.

Official website of the World Bank. Retrieved from: http://www.worldbank.org/

Orekhova, T (2007). Transnationalization economic systems in the conditions of globalization. - Donetsk: Donetsk National University. 394 p. 
Pebro, M. (1994). The International Economic, Financial and Currency relations. - Moscow: Progress: Unyvers. $496 \mathrm{p}$.

Rogach, A. (2003). International finance. - Kyiv. Lybid. 784 p.

Rogovyk, A. (2015). New Chinese dragons: global economic alternative is born. Retrieved from: http://bintel.com.ua/uk/article/drakon/

Slavuk, M. (2006). Money and credit. - Kyiv. Kyiv National University of Economics. 744 p.

Tsygankova, T. (2001). International organizations. - Kyiv: Kyiv National Economic University, 340 p.

\section{Андрей ОЛЕЙНИК \\ СИСТЕМА МЕЖДУНАРОДНЫХ ФИНАНСОВЫХ ОРГАНИЗАЦИЙ КАК ФАКТОР ТРАНСФОРМАЦИИ НАЦИОНАЛЬНОЙ ВАЛЮТНОЙ СИСТЕМЫ}

Аннотация. Целью работы является анализ теоретических и практических особенностей влияния международных финансовых организаций на трансформацию национальных валютных систем государствчленов этих организаций. Определение особенностей политики взаимодействия между национальной экономикой и МФО в валютной сфере, учитывая показатели социально-экономического развития станы, позволит монетарным органам власти достичь оптимального уровня развития своей экономики. Методика. Теоретическими основами исследования являются положения общей научной теории познания изучаемых явлений и процессов, в частности: методы индукции и дедукции (при определении критериев классификации воздействия международных финансовых организаций на национальную валютную систему), анализа и синтеза (при определении функций и приоритетов национальной валютной системы), сравнений, ассоциаций и аналогий (обоснование характеристик преимуществ и недостатков МФО). Информационной базой для проведения научного исследования стали научные статьи и публикаций отечественных и зарубежных ученых-экономистов, материалы научно-практических конференций, законодательных и нормативных документов, материалы МВФ, Всемирного банка и Азиатского банка инфраструктурных инвестиций. Результаты. Предложены теоретические подходы к определению национальной валютной системы и МФО, в том числе его классификацию МФО. Доказано, что МВФ активно влияет на формирование национальной валютной политики путем регулирования и надзора, в то время как Всемирный банк и АІІВ осуществляют пассивное влияние. Тенденциями регулирования МФО являются внедрение режима плавающего валютного курса, либеральные валютные операции, отсутствие валютных ограничений в странах-членах. Хотя это относится ко всем странам, некоторые из них с большим количеством населения, объемами торговли, слаборазвитыми институтами демократии могут избежать некоторого давления МФО. Практическое значение. Исследование акцентирует внимание на специфике деятельности международных финансовых институтов с точки зрения изменения валютной политики стран-членов. Сравнение приоритетов между национальной валютной политики и рекомендациями международных финансовых организаций могут быть применимы для национальных органов в проведении национальной валютной политики. Значение/ оригинальность. Несмотря на существующие исследования в области международной денежно-кредитной политики, существует пробел в теоретическом определении взаимодействия между МФО и национальными органами монетарной власти в области формирования национальной денежно-кредитной политики, в настоящее время. Эта статья открывает новые подходы к классификации международных финансовых институтов и определению характеристик МФО с точки зрения влияния на валютную политику страны-члена. 